\title{
Penanaman Karakter Anak Usia Dini dalam Kesenian Tradisional Tatah Sungging
}

\author{
Octavian Dwi Tanto $^{1 \bowtie}$, Hapidin $^{2}$, Asep Supena ${ }^{3}$ \\ Pendidikan Anak Usia Dini, Universitas Negeri Jakarta
}

\begin{abstract}
Abstrak
Penelitian ini bertujuan untuk mendeskripsikan temuan tentang penanaman karakter anak usia dini dalam kesenian tradisional tatah sungging di wilayah Kepuhsari, Wonogiri. Subjek penelitian ini adalah anak usia dini di wilayah Kepuhsari yang terampil dalam membuat karya-karya tatah sungging. Penelitian ini merupakan penelitian kulaitatif dengan jenis pendekatan etnografi model Spreadley. Hasil penelitian ini menunjukan bahwa keterlibatan anak usia dini dalam membuat karya tatah sungging mencerminkan karakternya seperti sabar, tekun, teliti, mandiri, tanggungjawab, disiplin, dan gotong royong yang terbentuk melalui dorongan, tuntutan, pembiasaan, dan keteladanan untuk menghasilkan karya secara presisi. Adapun ditemukan juga bahwa terdapat beberapa faktor pendukung yang mempengaruhi terbentuknya karakter anak dalam kesenian tradsional tatah sungging seperti nilai sejarah, nilai filosofis, persepsi masyarakat, penggunaan gaya bahasa, tingkat kesulitan dalam menghasilkan karya yang presisi, keterampilan anak dalam menghasilkan karya secara presisi, dan semangat pelestarian budaya pada masyarakat Kepuhsari.
\end{abstract}

Kata Kunci: penanaman karakter; karakter anak usia dini; seni tatah sungging

\begin{abstract}
This study aims to describe the findings about the formation of early childhood character in traditional art of tatah sungging in Kepuhsari, Wonogiri. The subjects of this study were early childhood in the Kepuhsari region who were skilled in making tatah sungging works. This research is a qualitative research with an ethnographic approach of Spreadley models. The results of this study indicate that the involvement of early childhood in making tatah sungging works reflects their character such as patience, diligence, thoroughness, independence, responsibility, discipline, and gotong royong that formed through the encouragement, demand, habituation, and exemplary to produce precision work. It also found that there are several supporting factors that influence the formation of early childhood character in traditional art of tatah sungging such as historical values, philosophical values, public perceptions, the use of language styles, the level of difficulty in producing precise work, children's skills in producing precision works, and the spirit of cultural preservation in the Kepuhsari community.
\end{abstract}

Keywords: character in early childhood, tatah sungging art

Copyright (c) 2019 Octavian Dwi Tanto, Hapidin, Asep Supena

$\triangle$ Corresponding author:

Address : UNJ, G. Daksinapati, Rawamangun Muka

ISSN 2356-1327 (Media Cetak)

Email : hapidin1964@gmail.com

ISSN 2549-8959 (Media Online) 


\section{PENDAHULUAN}

Kemajuan suatu bangsa ditentukan dari karakter sumber daya manusianya. Setiap bangsa maju memiliki kualitas sumber daya manusia yang berkarakter. Tentunya, karakter yang menjadi tolak ukur dari kemajuan suatu bangsa tersebut adalah karakter baik seperti jujur, tekun, gotong royong, disiplin, pekerja keras, mandiri, ulet, tanggungjawab, dan lain sebagainya.

Diera 4.0 ini, pendidikan karakter anak usia dini menjadi perhatian utama bagi para praktisi dan akademisi di Indonesia. Menurut Gultom, pendidikan karakter anak usia dini dijadikan sebagai upaya untuk mempersiapkan kualitas sumber daya manusia yang handal dalam menyongsong bonus demografi di tahun 2045 (Gultom, 2017, p. 39). Upaya ini tercatat dalam Perpres Nomor, 78 Tahun 2017 tentang Penguatan Pendidikan Karakter (PPK) yang menyatakan bahwa Anak Usia Dini (AUD) berada pada fase keemasan (the golden age) dalam pertumbuhan dan perkembangan manusia baik secara emosi, sosial, dan spiritual, sehingga untuk mendapatkan hasil efektif dan optimal, maka pendidikan karakter harus dimulai sejak usia dini (Kh \& Mukhlis, 2017, p. 42). Terbitnya perpres tersebut menunjukkan bahwa pemerintah serta seluruh stakeholder pendidikan di Indonesia serius dalam mencetak generasi penerus bangsa yang berkarakter.

Penanaman karakter seyogyanya memang diberikan sedini mungkin pada anak. Menurut Suprayekti, usia dini merupakan masa kritis bagi pembentukan karakter seseorang (Suprayekti, 2013, p. 54). Pada sumber yang sama ditegaskan bahwa kegagalan penanaman karakter sejak usia dini akan membentuk pribadi yang bermasalah dimasa dewasanya kelak (Suprayekti, 2013, p. 54). Pendapat tersebut mendeskripsikan bahwa penanaman karakter pada anak usia dini merupakan proses fundamental yang membentuk dasar kepribadian manusia.

Frediawan dan Putra memperjelas bahwa untuk memperkuat karakter dasar anak dibutuhkan pendidikan berbasis budaya lokal yang memiliki nilai kokoh dan dominan dalam membentuk karakter dasar seseorang (Ferdiawan \& Putra, 2013, p. 1097). Pandangan ini dapat dimaknai bahwa karakter dasar seseorang ditentukan dari pembentukan karakter diusia dini yang berkembang sesuai dengan kondisi lingkungannya. Setiap kondisi lingkungan tersebut mencerminkan bagaimana perilaku masyarakat lokal yang ditiru anak secara berulang-ulang hingga menjadi kebiasaan. Hal ini sebagaimana penjelasan Moraru dkk., bahwa anak-anak pada masa prasekolah adalah peniru teliti yang dapat menyalin berbagai model dengan ketepatan tinggi (Moraru, Gomez, \& McGuigan, 2016, p. 34). Artinya, penanaman karakter anak melalui pendidikan berbasis budaya lokal merupakan cara terbaik untuk membentuk karakter dasar seseorang.

Sejauh ini, terdapat banyak penelitian yang membahas tentang penanaman karakter melalui pendidikan berbasis budaya lokal. Contohnya, penelitian study literature dari Nasution yang membahas tentang pendidikan karakter berbasis kearifan lokal (Nasution, 2016, p. 102). Selain itu terdapat penelitian kualitatif dengan pendekatan case study dari Ghufronudin, dkk., yang membahas tentang representasi pendidikan karakter berbasis kearifan lokal melalui pembelajaran membatik (Ghufronudin, Zuber, \& Demartoto, 2017, p. 36). Sumber penelitian relevan lain juga ditulis oleh Wahyu dan Edu yang membahas tentang rekonstruksi nilai karakter berbasis budaya Manggarai (Wahyu \& Edu, 2018, pp. 1-6).

Selanjutnya, terdapat penelitian dengan pendekatan kualitatif dari Abubakar dkk., yang membahas tentang identifikasi 
beberapa nilai perbedaan dari Acehnese Malee (budaya rasa malu dari Aceh) sebagai pendidikan karakter (Abubakar, Srimulyani, \& Anwar, 2019, p. 137). Sumber relevan lain tercatat dari hasil penelitian Pelu dan Isawati yang membahas tentang nilai historis Candi Cetho sebagai sumber dan bahan pendidikan karakter berbasis budaya (Isawati \& Pelu, 2018, p. 400). Terbaru, terdapat penelitian Narawati yang membahas tentang pendidikan seni dan desain sebagai pembangunan karakter (Narawati, 2018, p. 167).

Berbagai hasil penelitian tersebut menunjukkan bahwa penanaman karakter berbasis budaya lokal merupakan cara terbaik untuk membentuk sumber daya manusia sekaligus membangun peradaban bangsa yang berkualitas. Hal ini dikarenakan setiap budaya memiliki nilai kearifan lokal yang mengatur tata tindak serta tata tutur masyarakat baik selama berinteraksi dengan individu, kelompok, maupun lingkungan alam sekitar. Nilai kearifan lokal tersebut tercermin dari ciri khas kebiasaan, tradisi, adat-istiadat, serta kesenian tradisional yang membudaya pada kehidupan masyarakat.

Sebagaimana hasil penelitian tersebut, masyarakat Desa Kepuhsari, Wonogiri, Jawa Tengah juga memiliki budaya yang masih melekat pada kehidupannya. Masyarakat Kepuhsari memiliki kebiasaan dalam membuat wayang kulit melalui kesenian tradisional yang dikenal dengan istilah kerajinan tatah sungging. Eksistensi ini dibuktikan dengan banyaknya pemberitaan dimedia cetak, postingan dimedia sosial seperti instagram @ desawisatakepuhsari dan twitter @kampungwayang_, serta upload-an di youtube yang memperlihatkan tentang keberadaan kesenian tatah sungging Kepuhsari. Bahkan terdapat sumber yang mengatakan bahwa kerajinan tatah sungging merupakan sumber mata pencaharian bagi penduduk Kepuhsari mulai dari kalangan anak usia sekolah dasar hingga orang dewasa usia di atas 60 tahun (Putri, 2015, p. 5)

Meskipun prosesnya sulit, namun karena dilakukan secara berulang-ulang kesulitan tersebut menjadi rutinitas yang biasa bagi anak. Hal ini terlihat dari keterampilan anak dalam membuat pola tatahan serta sunggingan wayang kulit yang presisi dengan bentuk pakemnya. Setiap pola tatahan serta sunggingan presisi tersebut menyimbolkan bagaimana watak penokohan wayang kulit. Penokohan wayang kulit berwatak protagonis disimbolkan melalui bentuk tatahan kepala ndingkluk, mulut mingkem, badan cenderung kurus dan proposional dengan tidak terlalu banyak perhiasan dibagian tubuhnya, serta komposisi sunggingan warna yang tidak terlalu kontras untuk mencerminkan ketawadhuannya. Sebaliknya, penokohan wayang berwatak antagonis digambarkan melalui bentuk tatahan kepala ndangak, mulut mangap, gigi bertaring, badan besar dan cenderung tidak proposional dengan banyak perhiasan dibagian tubuhnya, serta komposisi sunggingan warna yang kontras untuk mencerminkan kebengisannya.

Sementara itu, Marsudi mengatakan bahwa tatah sungging telah dikenal bangsa Indonesia sebagai seni kriya yang dimaknai agung dan berwibawa sehingga karya tatah sungging dapat dijumpai di pusat pemetintahan pada masa kerajaan kerajaan yang berkembang di Nusantara (Marsudi, 2013, p. 6). Tatah sungging merupakan kesenian yang berkaitan dengan wayang kulit. Seni tatah sungging merupakan perpaduan seni tatah dan sungging. Seni tatah berhubungan erat dengan pembuatan pola stilisasi, sedangkan seni sungging berkaitan erat dengan pemberian warna pada pola tersebut. Sehingga kedua hal tersebut dapat 
dipadukan menjadi seni tatah sungging (Seni tatah sungging, 1996, p. 8). Tatah sungging merupakan kegiatan menatah dan menyungging yang keduanya mempunyai teknik yang berbeda dalam proses pelaksanaannya.

Berdasarkan pandangan ahli serta hasil penelitian di atas dapat dilihat bahwa terdapat banyak penelitian yang mengkaji tentang kesenian tradisional tatah sungging dan penanaman nilai karakter. Meskipun demikian, namun belum terdapat satu pun yang penelitian serta pandangan ahli yang membahas tentang penanaman karakter melalui kesenian tradisional tatah sungging. Sementara itu hasil pengamatan awal menunjukkan bahwa keterlibatan anak yang terbiasa membantu orang tuanya untuk membuat karya-karya tatah sungging mencerminkan nilai-nilai karakternya. Komalasari dan Saripudin mengatakan bahwa karakter didefinisikan sebagai sekumpulan trait positif yang terefleksi dalam pikiran, perasaan, dan perilaku. Webster New Word Dictionary dalam (Komalasari \& Saripudin, 2017, p. 2) mendefinisikan karakter sebagai distinctive trait, distinctive quality, moral strength, the pattern of behaviour found in an individual or grup. Bahwa karakter merupakan ciri khas, kekuatan moral, dan pola perilaku yang ditemukan dalam individu atau kelompok. Menurut Lickona dalam (Yaumi, 2014, p. 7) "Character as knowing the good, desiring the good, and doing the good" yang berarti mengatahui kebaikan, menginginkan kebaikan, dan melakukan segala sesuatu yang baik.

Pembentukan perilaku hingga menjadi karakter dibagi menjadi tiga cara yaitu: (1) kondisioning atau pembiasaan, dengan membiasakan diri untuk berperilaku seperti yang diharapkan, akhirnya akan terbentuklah perilaku tersebut; pengertian (insight), cara ini mementingkan pengertian, dengan adanya pengertian mengenai perilaku akan terbentuklah perilaku; (3) model, dalam hal ini perilaku terbentuk karena adanya model atau teladan yang ditiru (Walgito, 2004, p. 79).

Karakter melekat pada setiap individu, yang tercermin pada pola perilaku dalam kehidupan sehari - hari. Karakter seseorang dipengaruhi oleh faktor lingkungan (nurture) dan faktor bawaan (nature). Istilah karakter berasal dari bahasa Yunani yaitu "charassein" yang berarti to engrave atau mengikir. Maka membentuk karakter diibaratkan seperti mengukir di atas batu permata atau permukaan besi yang keras (Komalasari \& Saripudin, 2017, p. 2).

Matta menambahkan bahwa terdapat faktor penghambat dan pendorong pembentukan karakter seseorang yaitu faktor internal dan faktor eksternal. Faktor internal merupakan semua unsur kepribadian yang secara kontinyu mempengaruhi perilaku manusia, yang meliputi instink biologis, kebutuhan psikologis, dan kebutuhan pemikiran. Sedangkan faktor eksternal adalah faktor yang bersumber dari luar manusia, akan tetapi dapat mempengaruhi perilaku manusia, baik langsung maupun tidak langsung (Matta, 2006, p. 16).

\section{METODOLOGI}

Metodologi yang digunakan dalam penelitian ini adalah etnografi. Tujuan utama dari reseach ini adalah untuk memperoleh gambaran umum hingga mendalam mengenai fokus penelitian yaitu penanaman karakter anak dalam kegiatan tatah sungging. Agar memperoleh data yang sesuai dengan fokus penelitian tersebut, sepanjang reseach ini berlangsung peneliti tinggal bersama keluarga pengerajin Kepuhsari yang memiliki anak terampil dalam membuat karya tatah sungging. 
Prosedur penelitian yang digunakan dalam qualitative research ini mengacu pada pendekatan etnografi model Spradley. Etnografi model Spradley bertujuan untuk menguraikan temuan penelitian tentang budaya serta aspek-aspeknya secara menyeluruh baik yang bersifat material seperti artefak (alat-alat, pakaian, bangunan, dan sebagainya) maupun bersifat abstrak seperti pengalaman, kepercayaan, norma, dan sistem nilai kelompok. Pandangan umum tersebut menggambarkan bahwa etnografi merupakan pendekatan dalam metode kualitatif yang digunakan untuk meneliti tema-tema budaya. Pendekatan ini secara teknis memiliki langkah-langkah prosedural yang dijelaskan oleh Sugiyono pada gambar bagan serta uraian di bawah ini;

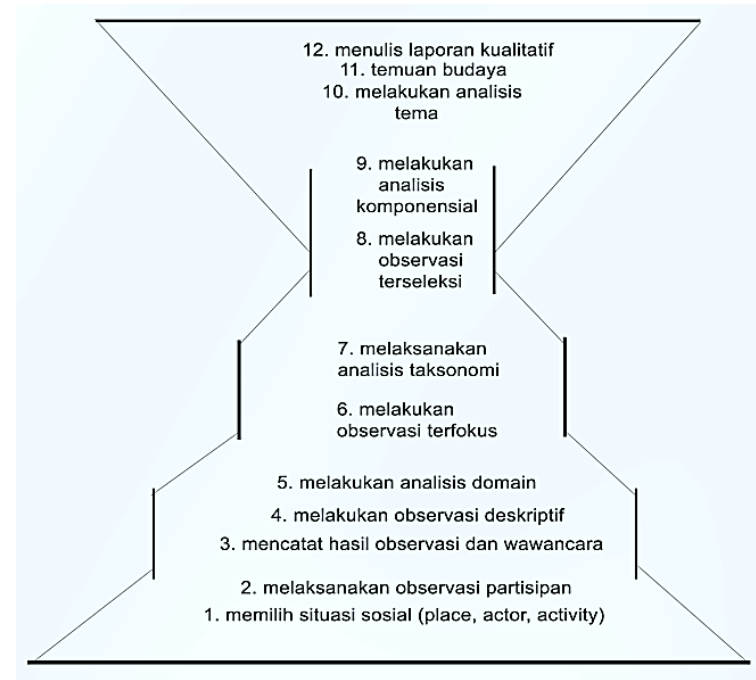

\section{Bagan 1. Langkah-langkah Prosedural Penelitian Etnografi (Sugiyono, 2007, p. 254)}

Selama penelitian ini berlangsung, peneliti mengamati subjek penelitian yaitu anak-anak Kepuhsari yang terampil dalam membuat karya tatah sungging dan pegerajin tatah sungging Kepuhsari. Pengamatan ini dilakukan secara mendalam dan menyeluruh hingga diperoleh pemahaman yang luas dan rinci mengenai fokus penelitian yaitu penanaman karakter anak dalam kesenian tradisional tatah sungging. Secara teknis fokus penelitian tersebut akan didalami menggunakan sub fokus penelitian antara lain; 1) bentuk penanaman karakter anak usia dini dalam kesenian tradisional tatah sungging, 2) proses penanaman karakter anak usia dini dalam kesenian tradisional tatah sungging, dan 3) faktor pendukung serta penghambat penanaman karakter anak usia dini dalam kesenian tradisional tatah sungging

Melalui teknik pengumpulan data observasi partisipatif, wawancara secara mendalam, serta dokumentasi, data-data yang berasal dari subjek penelitian diperoleh dan selanjutnya dianalisis. Teknik analisis data yang digunakan dalam penelitian ini adalah teknik analisis data etnografi Spradley. Menurut Spradley, model pendekatan reseach tersebut digunakan untuk membangun pengertian yang sistematik mengenai semua kebudayaan manusia dari perpektif peneliti (Spradley, 1997, p. 12). Secara prosedur, langkah-langkah teknik analisis data tersebut dimulai dari analisis domain atau mencari gambaran umum penelitian, kemudian dilanjutkan dengan analisis taxonomi atau memperdalam gambaran umum penelitian, dan dilanjutkan dengan analisis komponensial atau memperoleh pemahaman kontras terhadap data, hingga diakhiri dengan analisis tema atau mencari benang merah dari keseluruhan domain yang ditemukan.

\section{HASIL DAN PEMBAHASAN}

Berdasarkan hasil pengamatan lapangan, ditemukan bahwa terdapat karakter anak yang terbentuk sepanjang dibiasakan orang tuanya untuk membuat kerajinan tatah sungging secara presisi. Nilai-nilai karakter seperti sabar, tekun, teliti, mandiri, tanggungjawab, disiplin, dan gotong royong muncul sepanjang anak dibiasakan oleh orang tuanya untuk melakukan kegiatan seni tatah sungging. 
Hal ini dapat dilihat dari keseharian anakanak Kepuhsari yang dilibatkan oleh orang tuanya dalam pembuatan karya-karya kerajinan tatah sungging.

Terbentuknya karakter anak Kepuhsari melalui kegiatan kerajinan tatah sungging dipengaruhi oleh kebiasaan. Kebiasaan yang ada sejak dini akan bertahan hingga anak dewasa dan orangtua dapat mempengaruhi baik atau buruk dalam pembentukan kebiasaan tersebut (Lickona, 2012, p. 50). Lebih lanjut, Lickona juga memaparkan bahwa keluarga merupakan pihak pertama dan penting dalam mempengaruhi karakter anak (Lickona, 2012, p. 81). Berdasarkan pendapat tersebut dapat dikatakan bahwa pembentukan karakter dipengaruhi oleh lingkungan terdekat anak yaitu keluarga melalui kebiasaan - kebiasaan dan pengaruh dari orangtua kepada anak sejak dini.

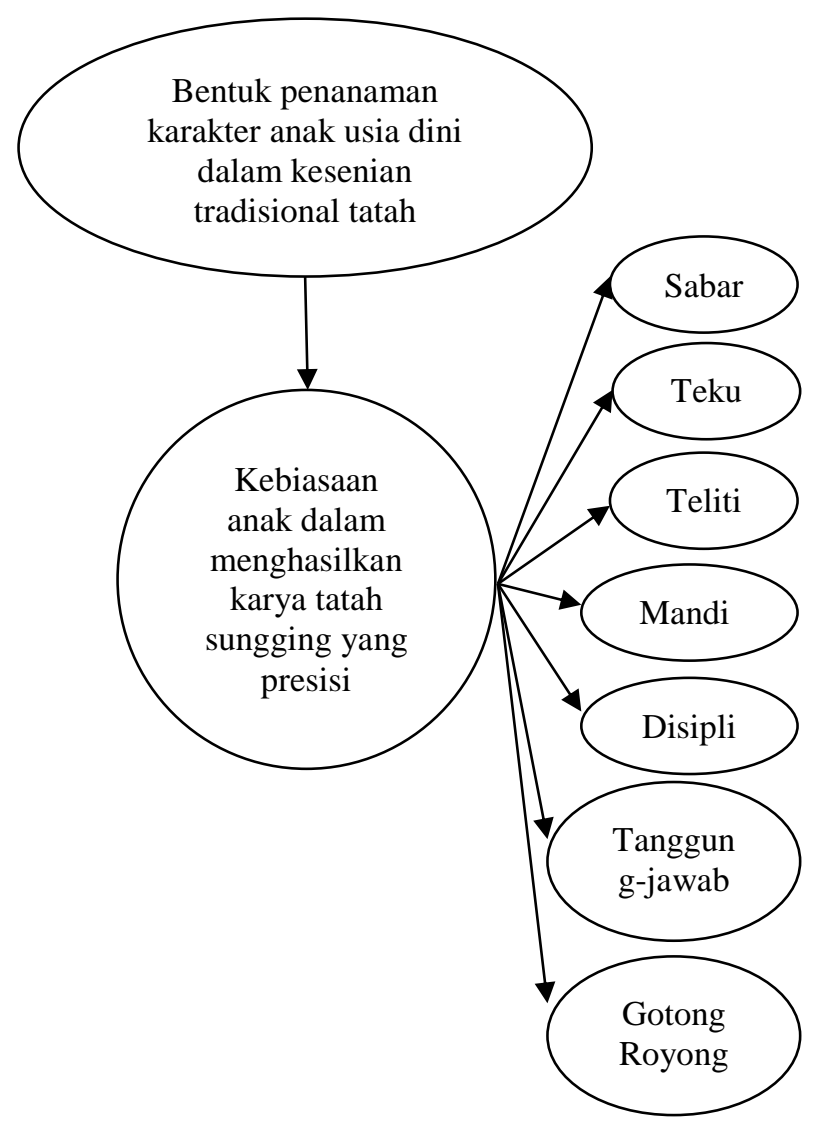

Bagan 2. Temuan Bentuk Penanaman Karakter Anak Usia Dini dalam Kesenian Tradisional Tatah Sungging
Temuan tersebut didukung oleh pendapat Musfiroh dalam (Ingsih, Ratnawati, Nuryanto, \& Astuti, 2018, p. 19) yang mengatakan bahwa pembentukan karakter merupakan upaya meningkatkan perilaku individu yang dilakukan secara berkesinambungan melibatkan aspek knowledge, feeling, dan acting. Adapun tujuannya adalah agar anak mempraktekkan langsung nilai-nilai tersebut dan terbiasa untuk melakukan hal-hal yang baik dengan harapan nilai tersebut dapat terinternalisasi dalam kehidupan anak.

Disamping itu, Saptono mengatakan bahwa proses penanaman karakter dipandang sebagai usaha sadar dan terencana, bukan usaha yang sifatnya terjadi secara kebetulan. Atas dasar ini, pendidikan karakter adalah usaha yang sungguhsungguh untuk memahami, membentuk, memupuk nilai-nilai etika, baik untuk diri sendiri maupun semua warga masyarakat secara keseluruhan (Saptono, 2011, p. 23).

Disamping itu, ditemukan juga bahwa terdapat beberapa proses terbentuknya karakter anak usia dini melalui kesenian tradisional tatah sungging antaralain; 1) dorongan menghasilkan karya presisi menggunakan alat dan bahan tatah sungging, 2) tuntutan memiliki keterampilan dalam membuat karya presisi menggunakan alat dan bahan tatah sungging, 3) pembiasaan terampil dalam membuat karya karya presisi menggunakan alat dan bahan tatah sungging, dan 4) keteladanan dalam melakukan kegiatan tatah sungging dengan menghasilkan karya yang presisi.

Sesuai dengan temuan diatas, bahwa pembentukan perilaku hingga menjadi karakter dibagi menjadi tiga cara yaitu: (1) kondisioning atau pembiasaan, dengan membiasakan diri untuk berperilaku seperti yang diharapkan, akhirnya akan terbentuklah perilaku tersebut; (2) pengertian (insight), cara ini mementingkan 
pengertian, dengan adanya pengertian mengenai perilaku akan terbentuklah perilaku; (3) model, dalam hal ini perilaku terbentuk karena adanya model atau teladan yang ditiru (Walgito, 2004, p. 79).

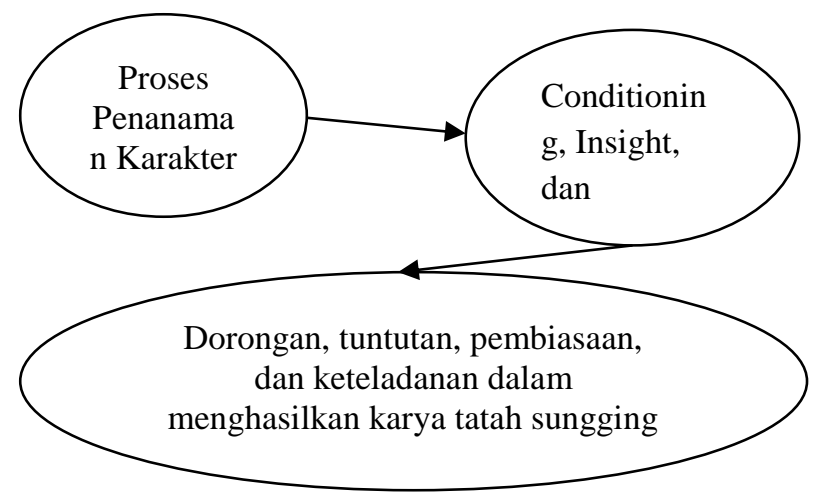

Bagan 3. Proses Penanaman Karakter Anak Usia Dini dalam Kesenian Tradisional Tatah Sungging

Menurut Albertus, terdapat beberapa hal yang perlu diperhatikan dalam membentuk karakter anak, yaitu pembiasaan tingkah laku sopan, kesadaran terhadap kebersihan, kerapian, dan ketertiban, serta pembiasaan untuk berlaku jujur dan bersikap disiplin. Dari beberapa hal tersebut dapat dikatakan bahwa pembentukan karakter adalah segala sesuatu yang dilakukan oleh orang tua untuk mempengaruhi karakter anak. Orang tua membantu membentuk karakter anak dengan memberikan keteladanan, cara berbicara atau menyampaikan sesuatu yang baik, toleransi, dan hal yang terkait lainnya (Albertus, 2010, p. 80).

Adapun dalam penelitian ini ditemukan juga bahwa terdapat faktor pendukung dan penghambat penanaman karakter anak usia dini dalam kesenian tatah sungging. Faktor pendukung terbentuknya karakter anak dalam kesenian tatah sungging dapat dilihat dari beberapa temuan domain mulai dari aspek nilai sejarah, nilai filosofis, persepsi masyarakat, penggunaan gaya bahasa, tingkat kesulitan dalam menghasilkan karya yang presisi, keterampilan anak dalam menghasilkan karya secara presisi, hingga semangat pelestarian budaya pada masyarakat Kepuhsari.

Serupa dengan hasil penelitian di atas, Zubaedi juga menyatakan bahwa keluarga merupakan wahana pertama dan pertama bagi pendidikan karakter anak. Apabila keluarga gagal melakukan pendidikan pada anaknya, maka akan sulit bagi institusi institusi lain di luar keluarga termasuk sekolah untuk memperbaikinya. Kegagalan keluarga dalam membentuk karakter anak akan berakibat pada tumbuhnya masyarakat yang tidak berkarakter. Oleh karena itu, setiap keluarga harus memiliki kesadaran bahwa karakter bangsa sangat bergantung pada pendidikan karakter anak di rumah (Zubaedi, 2012, p. 145).

Kartono memaparkan bahwa terdapat dua faktor yang mempengaruhi terbentuknya karakter yaitu faktor biologis dan faktor lingkungan. Faktor biologis yaitu faktor yang berasal dari dalam diri seseorang. Faktor ini berasal dari keturunan atau bawaan yang dibawa sejak lahir dan pengaruh keturunan dari salah satu sifat yang dimiliki salah satu atau kedua orangtuanya. Sedangkan faktor lingkungan, yaitu pengaruh dari lingkungan, pendidikan, kondisi, situasi hidup, dan kondisi masyarakat (Kartono, 2005, p. 16). Berdasarkan uraian pendapat diatas, dapat dikatakan bahwa terdapat dua faktor yang akan mempengaruhi pembentukan karakter pada anak. Faktor tersebut adalah faktor bawaan dan faktor lingkungan. Faktor bawaan merupakan apa yang anak punya sejak sebelum lahir, sedangkan faktor lingkungan adalah pengaruh yang diberikan oleh lingkungan pada anak setelah lahir.

Selain faktor pendukung ditemukan juga faktor penghambat dalam penelitian ini antara lain; 1) Terbatasnya waktu orangtua untuk membelajarkan tatah sungging, 2) Penggunaan gadget yang berlebihan, 3) 
Melihat tayangan TV yang berlebihan, 4) Banyaknya kegiatan budaya yang dilakukan anak usia dini di Kepuhsari, dan 5) Terbatasnya waktu untuk belajar di sanggar.

Menurut Matta, faktor penghambat dan pendorong pembentukan karakter seseorang dipengaruhi oleh faktor internal dan faktor eksternal. Faktor internal merupakan semua unsur kepribadian yang secara kontinyu mempengaruhi perilaku manusia, yang meliputi instink biologis, kebutuhan psikologis, dan kebutuhan pemikiran. Sedangkan faktor eksternal adalah faktor yang bersumber dari luar manusia, akan tetapi dapat mempengaruhi perilaku manusia, baik langsung maupun tidak langsung (Matta, 2006, p. 16). Lebih spesifik, Rahmat dalam (Domara, 2015, p. 23) juga memaparkan faktor yang mempengaruhi terbentuknya karakter menjadi sua faktor yaitu faktor yang ada dalam diri dan faktor dari luar diri. Faktor yang ada dalam dirinya antara lain: insting, kepercayaan, keinginan, hati nurani, dan hawa nafsu. Sementara itu faktor dari luar antara lain: lingkungan, rumah tangga dan sekolah, pergaulan teman dan sahabat, serta penguasa atau pemimpin.

\section{KESIMPULAN}

Tatah Sungging merupakan simbol dari eksistensi budaya wayang kulit yang mencerminkan nilai-nilai karakter bagi anak usia dini di wilayah Kepuhsari. Anak-anak Kepuhsari yang terampil dalam membuat karya tatah sungging selalu dibiasakan oleh orang tuanya untuk menghasilkan karya yang presisi. Pembiasaan dalam menghasilkan karya tatah sungging yang presisi tersebut dapat digunakan sebagai sarana bagi para orang tua untuk menstimulasi nilai-nilai karakter pada anak usia dini yang terampil dalam melakukan setiap tahap kegiatan ini mulai dari menyorek atau megeblak, menatah, dan menyungging.

\section{UCAPAN TERIMA KASIH}

Ucapan terima kasih diucapkan oleh penulis kepada orang tua, keluarga, serta teman-teman yang mendoakan serta mendukung terselesainya penelitian ini. Disamping itu ucapan terima kasih juga diucapkan juga oleh penulis kepada dosen pembimbing I yaitu Dr. Hapidin, M.Pd., dan dosen pembimbing II yaitu Dr. Asep Supena, M.Psi.

\section{DAFTAR PUSTAKA}

Abubakar, Srimulyani, E., \& Anwar. (2019). Identification of some distinctive values Of Acehnese Malee (shyness) for character education. Jurnal Ilmiah Peuradeun, 7, 125-140.

Albertus, K. D. (2010). Pendidikan karakter strategi mendidik anak di zaman global. Jakarta: PT Grasindo.

Domara, D. (2015). Upaya guru pendidikan agama Islam dalam membentuk karakter peserta didik. IAIN Tulungagung.

Ferdiawan, E., \& Putra, W. E. (2013). Esq education for children character building based on psylosophy of Javaness in Indonesia. Social and Behavioral Sciences, 106, 1096-1102. https://doi.org/10.1016/j.sbspro.2013.1 2.123

Ghufronudin, Zuber, A., \& Demartoto, A. (2017). Representasi pendidikan karakter berbasis kearifan lokal melalui pembelajaran membatik. Jurnal Analisa Sosiologi, 6(2), 30-37.

Gultom, O. (2017). Peranan pendidikan karakter anak usia dini terhadap generasi emas. Prosiding Seminar Nasional Tahunan, 1, 34-40.

Ingsih, K., Ratnawati, J., Nuryanto, I., \& Astuti, S. D. (2018). Pendidikan 
karakter (alat peraga edukatif media interaktif). Yogyakarta: Deepublish.

Isawati, \& Pelu, M. (2018). Historical value of cetho temple as local culture - based character education source and material. Advances in Social Science, Education and Humanities Research, 279.

Kartono, K. (2005). Teori kepribadian. Bandung: Mandar Maju.

Kh, E. F. F., \& Mukhlis, G. N. (2017). Pendidikan karakter untuk anak usia dini menurut Q.S. Lukman: 13 - 19. PEDAGOGI: Jurnal Anak Usia Dini Dan Pendidikan Anak Usia Dini, 3(3a).

Komalasari, K., \& Saripudin, D. (2017). Pendidikan karakter (konsep dan aplikasi living values education). Bandung: PT Refika Aditama.

Lickona, T. (2012). Character matters. Jakarta: Bumi Aksara.

Marsudi. (2013). Produk kulit tatah sungging $I$.

Matta, M. A. (2006). Membentuk karakter cara Islam. Jakarta: Al-I'tishom Cahaya Umat.

Moraru, C.-A., Gomez, J.-C., \& McGuigan, N. (2016). Developmental changes in the influence of conventional and instrumental cues on over-imitation in 3- to 6-year-old children. Journal of Experimental Child Psychology, 145, 34-47.

Narawati, T. (2018). Arts and design education for character building. Advances in Social Science, Education and Humanities Research, 255.

Nasution, M. (2016). Character education based on local wisdom. International Joint Seminar on The Contribution of Education Institution to ASEAN Economic Community, 99-102.

Putri, F. E. (2015). Pengembangan UMKM Di Desa Kepuhsari Wonogiri melalui kegiatan assessment dan bina desa.
Saptono. (2011). Dimensi - dimensi pendidikan karakter. Salatiga: Erlangga.

Seni tatah sungging. (1996). Departemen Pendidikan dan Kebudayaan Kantor Wilayah Provinsi Jawa Tengah.

Spradley, J. P. (1997). Metode etnografi. Yogyakarta: PT Tiara Wacana Yogya.

Sugiyono. (2007). Penelitian Kualitatif Kuantutaif dan $R \& D$.

Suprayekti. (2013). Pengembangan bahan belajar "pendidikan karakater anak usia sekolah dasar" untuk orang tua. Perspektif Ilmu Pendidikan, 27.

Wahyu, Y., \& Edu, A. L. (2018). Reconstruction of character values based on Manggaraian culture. SHS Web of Conferences, 42. https://doi.org/10.1051/shsconf/20184 200029

Walgito, B. (2004). Pengantar psikologi umum. Yogyakarta: Fakultas Psikologi UGM.

Yaumi, M. (2014). Pendidikan karakter: landasan, pilar, dan implementasi. Jakarta: Prenadamedia Group.

Zubaedi. (2012). Desain pendidikan karakter konsepsi dan aplikasinya dalam dunia pendidikan. Jakarta: Kencana. 